\title{
PENGARUH GENDER DIVERSITY, PROFITABILITAS, UKURAN PERUSAHAAN, UKURAN KAP TERHADAP PENGUNGKAPAN TANGGUNG JAWAB SOSIAL PERUSAHAAN
}

\author{
Ulfa Luthfia Nanda \\ Universitas Perjuangan Tasikmalaya \\ Gista Rismayani \\ Universitas Perjuangan Tasikmalaya \\ *ul_nanda@yahoo.com
}

\begin{abstract}
This paper is aimed to analyse influence of gender diversity, profitability, firm size, audit firm size to corporate social responsibility disclosure. This study use purposive sampling method. Subject of research are food and beverage companies. Sampel of this study are consisted 4 companies which listed in Indonesia Stock Exchange during 2015-2017. Data processing in this study use Software SPSS. Result of examination hypothesis of this study that gender diversity, profitability and audit firm size have no effect significantly on corporate social responsibility disclosure whether firm size have effect significantly on corporate social responsibility disclosure.
\end{abstract}

Keywords : corporate social responsibility, gender diversity, profitability, firm size, audit firm size

\section{PENDAHULUAN}

Semakin banyak perusahaan dan industri yang melakukan kegiatan bisnis, menandakan semakin berkembangnya kegiatan bisnis di suatu negara. Berdirinya suatu perusahaan dapat membantu meningkatkan pertumbuhan ekonomi dan kesejahteraan sosial. Selain dianggap sebagai lembaga yang memberikan banyak keuntungan bagi masyarakat, perusahaan juga menjadi penyebab kerusakan alam di Indonesia (Z, Makhdalena, dan Trisnawati, 2016). Kerusakan alam tersebut disebabkan oleh aktivitas dan kegiatan operasional perusahaan yang mengakibatkan terjadinya bencana alam, perubahan iklim, kerusakan ekosistem dan pencemaran lingkungan (Sanjaya, Taufik, dan L, 2014). Adanya dampak dari kerusakan alam yang ditimbulkan oleh perusahaan tersebut, membuat masyarakat menuntut pertanggungjawaban agar senantiasa memperhatikan dampakdampak sosial yang di timbulkan serta 66 upaya dalam mengatasinya (Rakhiemah dan Agustia, 2009). Perkembangan CSR juga didorong oleh revolusi teknologi komunikasi dan didukung oleh perubahan politik, ekonomi, dan sosial. Jatuhnya komunisme, liberalisasi di China, Vietnam dan India, munculnya kegiatan sektor lembaga non-pemerintah (LSM), paham kesadaran lingkungan (environmentalism), fundamentalisme, konsumerisme, proteksi, World Social Forum, dsb.

Tanggung jawab sosial perusahaan atau Corporate Social Responsibility (CSR) merupakan sebuah bentuk pertanggungjawaban perusahaan kepada para stakeholders dengan memperhatikan aspek sosial dan aspek lingkungan yang ada disekitar perusahaan. Peraturan Pemerintah Republik Indonesia No. 47 Tahun 2012 tentang Tanggung Jawab Sosial dan Lingkungan Perseroan Terbatas mengungkapkan bahwa setiap Perseroan atau entitas yang berbadan hukum 
memiliki tanggungjawab sosial dan lingkungan.

Subsektor makanan dan minuman merupakan salah satu subsektor yang ada di industri manufaktur yang memiliki peranan penting dalam pembangunan. Dengan dibukanya AFTA, banyak perusahaan asing maupun local di Indonesia berlomba-lomba untuk memajukan usahanya, hal ini seperti pisau bermata dua, di satu sisi perusahaanperusahaan tersebut mampu mencukupi kebutuhan masyarakat dan dengan sendirinya juga menguntungkan para shareholder, namun di sisi lain banyak terjadi pencemaran lingkungan oleh perusahaan tersebut. Jika hal tersebut terus berlanjut maka daya saing produk yang ada di subsector makanan dan minuman akan semakin terpuruk karena produk Indonesia cenderung lebih mahal dibandingkan produk asing. Kondisi daya saing produk Indonesia yang rendah akan mempengaruhi pertumbuhan ekonomi, kinerja perekonomian.

Berdasarkan survey global yang dilakukan The Economist Inteligence Unit mengatakan bahwa $85 \%$ eksekutif senior dan investor dari berbagai organisasi telah menjadikan CSR sebagai pertimbangan utama dalam pengambilan keputusan (Nurkhin, 2009). Pengunaan CSR sebagai pengambilan keputusan, seharusnya membuat perusahaan meningkatkan kualitas informasi pelaksanaan tanggung jawab sosial lingkungan dengan memperluas pengungkapan CSRnya (Nugroho dan Yulianto, 2015). Nurkhin (2009) menemukan adanya hubungan yang signifikan antara independent commissioner board, profitability, dan pengungkapan CSR. Purnasiwi (2011) mengungkapkan bahwa ukuran perusahaan, profitabilitas dan leverage berpengaruh secara signifikan terhadap pengungkapan tanggung jawab sosial perusahaan yang terdaftar dalam Bursa Efek Indonesia pada tahun 2009.

Berdasarkan latar belakang tersebut, peneliti tertarik untuk melakukan penelitian dengan judul " Pengaruh Gender Diversity, Profitabilitas, Ukuran Perusahaan, Ukuran KAP Terhadap Pengungkapan Tanggung Jawab Sosial Perusahaan pada Perusahaan Makanan dan Minuman yang Terdaftar Di Bursa Efek Indonesia".

\section{METODOLOGI PENELITIAN}

Populasi penelitian ini adalah perusahaan manufaktur sub sector makanan dan minuman yang terdaftar di Bursa Efek Indonesia dari tahun 2015 sampai 2017. Dalam menentukan sampel untuk memperoleh data yang dibutuhkan, penulis menggunakan teknik purposive. Sampel penelitian sebanyak 4 perusahaan, diambil melalui metode purposive sampling. Data yang digunakan adalah data sekunder yang diperoleh dari website Bursa Efek Indonesia.

\section{HASIL DAN PEMBAHASAN Hasil Penelitian}

\section{Hasil Analisis Deskriptif}

Tabel 1.2

Statistik Deskriptif

\begin{tabular}{lrrrr}
\hline \multicolumn{1}{c}{ Variabel } & Min. & $\begin{array}{c}\text { Max } \\
\text { ・ }\end{array}$ & Mean & $\begin{array}{c}\text { Std. } \\
\text { Deviatio } \\
\text { n }\end{array}$ \\
\hline CSR & 0,29 & 0,86 & 0,6083 & 0,25258 \\
Gender & 0,10 & 0,40 & 0,1854 & 0,10968 \\
$\begin{array}{l}\text { Diversity } \\
\text { Profitabilita }\end{array}$ & 0,05 & 0,23 & 0,1425 & 0,5612 \\
s & & & & \\
Ukuran & 27,3 & 32,1 & 29,906 & 1,82241 \\
$\begin{array}{l}\text { Perusahaan } \\
\text { Ukuran }\end{array}$ & 6 & 5 & 3 & \\
KAP & 0,00 & 1,00 & 0,75 & 0,45227 \\
Sumber : Data & & & \\
\end{tabular}

Sumber : Data sekunder diolah

Tabel di atas menunjukan variabel pengungkapan tanggung jawab social perusahaan (CSRDI) memiliki nilai minimum sebesar 0.29 dan nilai maksimum 0,86. Hal tersebut berarti bahwa perusahaan yang paling sedikit mengungkapkan tanggung jawab perusahaan (CSR) adalah PT. Sekar Bumi, 
Tbk dan yang paling banyak mengungkapkan tanggung jawab social perusahaan yaitu PT. Indofood Sukses Makmur, Tbk. Rata-rata pengungkapan tanggung jawab social perusahaan untuk keseluruhan sampel sebesar 0,608 atau $60,8 \%$. Nilai standar deviasi sebesar 0,2522 menunjukan besaran variasi pengungkapan tanggung jawab social yang dilakukan oleh perusahaan sektor makanan dan minuman.

Selanjutnya hasil analisis statistic deskriptif untuk variabel gender diversity menunjukan nilai minimum 0,1 dan maksimum 0,4. Hal tersebut berarti bahwa keberagaman gender terendah atau jumlah terendah untuk anggota direksi perempuan yang terdapat pada perusahaan sampel yaitu oleh PT. Indofood Sukses Makmur, Tbk dan keberagaman gender tertinggi yaitu oleh PT. Nippon Indosari Corporindo, Tbk. Rata-rata nilai gender diversity untuk keseluruhan sampel sebesar 0,185 atau $18,5 \%$. Nilai standar deviasi sebesar 0,1096 menunjukan besaran variasi gender diversity yang dimiliki oleh perusahaan sektor makanan dan minuman.

Hasil analisis statistic deskriptif untuk variabel profitabilitas menunjukan nilai minimum 0,05 dan maksimum 0,23. Hal tersebut berarti bahwa nilai profitabilitas yang diproksikan oleh ROE dengan nilai terendah yaitu oleh PT. Nippon Indosari Corporindo, Tbk tahun 2017 dan profitabilitas yang diproksikan oleh ROE dengan nilai tertinggi yaitu oleh PT. Nippon Indosari Corporindo, Tbk tahun 2015. Rata-rata nilai profitabilitas untuk keseluruhan sampel sebesar 0,142

\section{Hasil Uji Asumsi Klasik a. Uji Normalitas}

Tabel 1.3

Uji Normalitas

\begin{tabular}{cll}
\hline Variabel & $\begin{array}{l}\text { (Signifika } \\
\text { nsi) }\end{array}$ & $\begin{array}{l}\text { Keterang } \\
\text { an }\end{array}$ \\
\hline Unstandardi & 0,823 & Berdistrib \\
zed residual & & $\begin{array}{l}\text { usi } \\
\text { normal }\end{array}$
\end{tabular}

atau $14,2 \%$. Nilai standar deviasi sebesar 0,056 menunjukan besaran variasi nilai profitabilitas yang terdapat dalam perusahaan sektor makanan dan minuman.

Hasil analisis statistic deskriptif untuk ukuran perusahaan nilai minimum yang ditunjukan 27,36 dan maksimum 32,15 . Hal tersebut berarti bahwa Ukuran perusahaan dengan nilai terendah yaitu oleh PT. Sekar Bumi, Tbk tahun 2015 dan nilai ukuran perusahaan tertinggi yaitu oleh PT. Indofood Sukses Makmur tahun 2015, Tbk tahun 2015. Rata-rata nilai ukuran perusahaan untuk keseluruhan sampel sebesar 29,90. Nilai standar deviasi sebesar 1,822 menunjukan besaran variasi nilai ukuran perusahaan yang terdapat dalam perusahaan sektor makanan dan minuman.

Sementara hasil analisis statistic deskriptif untuk variabel ukuran KAP menunjukan nilai minimum 0,00 dan maksimum 1,00. Hal tersebut berarti bahwa 0 adalah untuk perusahaan yang tidak menggunakan jasa KAP yang tidak berafiliasi dengan KAP Big Four yaitu PT. Sekar Bumi, Tbk sementara 1 adalah untuk perusahaan yang menggunakan jasa KAP yang berafiliasi dengan KAP Big Four, yaitu PT. Indofood CBP Sukses Makmur, Tbk, PT. Indofood Sukses Makmur, Tbk dan PT. Nippon Indosari Corporindo, Tbk. Rata-rata nilai ukuran KAP untuk keseluruhan sampel sebesar 0,75. Nilai standar deviasi sebesar 0,452 menunjukan besaran variasi ukuran KAP yang terdapat dalam perusahaan sektor makanan dan minuman.

Sumber : Data sekunder diolah

Berdasarkan tabel 5.2, hasil yang ditujukan terdapat signifikansi di atas 0,05 yang berarti bahwa model regresi dalam penelitian ini berdistribusi normal. 


\section{b. Uji Multikoliniaritas}

Tabel 1.4

Uji Multikolinearitas

\begin{tabular}{lcc}
\hline \multicolumn{1}{c}{ Variabel } & Tolerance & $\begin{array}{c}\text { Variance } \\
\text { Inflation } \\
\text { Factor } \\
\text { (VIF) }\end{array}$ \\
\hline Gender Diversity & 0,304 & 3,090 \\
Profitabilitas & 0,702 & 1,425 \\
Ukuran & 0,148 & 6,777 \\
Perusahaan & & \\
Ukuran KAP & 0,228 & 4,378
\end{tabular}

Sumber : Data sekunder diolah

Berdasarkan tabel 5.3 hasil uji multikolinearitas, nilai Variance Inflation Factor menunjukan bahwa variabel independen memiliki nilai VIF kurang dari 10. Sementara nilai Tolerance menunjukan bahwa variabel independen memiliki nilai 0,1 . Sehingga dapat disimpulkan bahwa tidak terjadi multikolinearitas antar variabel.

\section{c. Uji Autokorelasi}

Tabel 1.5

Uji Autokorelasi

\begin{tabular}{ll}
\hline Asymp. Sign & \multicolumn{1}{c}{ Keterangan } \\
\hline 0,364 & $\begin{array}{l}\text { Tidak terjadi } \\
\text { autokorelasi }\end{array}$
\end{tabular}

Sumber : Data sekunder diolah

Berdasarkan tabel 5.4, hasil uji autokorelasi dengan Run Test diperoleh perhitungan 0,364 (di atas 0,05). Angka tersebut menunjukan bahwa tidak terjadi autokorelasi pada model regresi dalam penelitian ini.

\section{d. Uji heteroskedastisitas \\ Tabel 1.6}

Uji Heteroskedastisitas

\begin{tabular}{|c|c|c|}
\hline Variabel & Sig. & Keterangan \\
\hline Gender & 0,724 & Tidak terjadi \\
\hline Diversity & & heteroskedastisitas \\
\hline Profitabilitas & 0,762 & $\begin{array}{l}\text { Tidak terjadi } \\
\text { heteroskedastisitas }\end{array}$ \\
\hline Ukuran & 0,572 & Tidak terjadi \\
\hline Perusahaan & & heteroskedastisitas \\
\hline Ukuran KAP & 0,931 & $\begin{array}{l}\text { Tidak terjadi } \\
\text { heteroskedastisitas }\end{array}$ \\
\hline
\end{tabular}

Berdasarkan tabel 5.5, hasil uji heteroskedastiitas dengan metode Spearman's menunjukan bahwa nilai semua variabel independen, yaitu gender diversity, profitabilitas, ukuran perusahaan dan ukuran KAP memiliki nilai signifikansi di atas 0,05 , yang berarti bahwa tidak terdapat gejala heteroskedastisitas.

\section{e. Koefisien Determinasi}

Tabel 1.7

Koefisien Determinasi

\begin{tabular}{ccccc}
\hline $\begin{array}{c}\text { Mode } \\
\mathbf{l}\end{array}$ & $\mathbf{R}$ & $\mathbf{R}^{2}$ & $\begin{array}{c}\text { Adjusted. } \\
\boldsymbol{R} 2\end{array}$ & $\begin{array}{c}\text { Std. } \\
\text { Error of } \\
\text { Estimate }\end{array}$ \\
\hline 1 & 0,986 & 0,971 & 0,985 & 0,0535 \\
& \multicolumn{3}{c}{ Sumber : Data sekunder diolah } \\
\multicolumn{4}{c}{ Berdasarkan hasil yang ditunjukan }
\end{tabular}

oleh tabel 5.6, nilai koefisien determinasi yang ditunjukan oleh nilai adjusted $R^{2}$ sebesar 0,985. Hal ini berarti bahwa 98,5\% variasi indeks pengungkapan tanggung jawab social perusahaan dapat dijelaskan oleh variabel gender diversity, profitabilitas, ukuran perusahaan dan ukuran KAP. Sedangkan sisanya sebesar $0,15 \%$ dapat dijelaskan oleh variabel lain. Nilai R2 sebesar 0,971 menunjukan bahwa koefisien korelasi sebesar 97,1\% yang berarti bahwa antara gender diversity, profitabilitas, ukuran perusahaan dan ukuran KAP dengan pengungkapan 
tanggung jawab social perusahaan memiliki hubungan yang kuat.

\section{Hasil Analisis Regresi Berganda}

Tabel 1.8

Analisis Regresi Linear Berganda

\begin{tabular}{lcc}
\hline Variabel & $\begin{array}{c}\text { Unstandard } \\
\text { ized } \\
\text { Coefficient }\end{array}$ & $\begin{array}{c}\text { Standardi } \\
\text { zed } \\
\text { Coefficie } \\
\text { nt }\end{array}$ \\
\hline $\begin{array}{l}\text { Gender } \\
\text { Diversity }\end{array}$ & $-0,232$ & $-1,01$ \\
$\begin{array}{l}\text { Profitabil } \\
\text { itas }\end{array}$ & 0,410 & 0,091 \\
$\begin{array}{l}\text { Ukuran } \\
\text { Perusaha } \\
\text { an }\end{array}$ & 0,121 & 0,023 \\
$\begin{array}{l}\text { Ukuran } \\
\text { KAP }\end{array}$ & 0,025 & 0,075 \\
\hline
\end{tabular}

Sumber : Data sekunder diolah

Analisis regresi linear berganda seperti yang ditunjukan oleh tabel 5.7 dengan tingkat signifikansi sebesar 5\% diperoleh persamaan sebagai berikut :

\section{$\mathrm{Y}=\mathbf{- 3 , 0 4 7}-\mathbf{0 , 2 3 2} \mathrm{CSRDI}+\mathbf{0 , 4 1 0} \mathrm{ROE}$ $+0,121$ SIZE + 0,025 KAP + e}

Persamaan tersebut di atas menunjukan bahwa variabel independen yang terdiri dari profitabilitas, ukuran perusahaan dan ukuran KAP memiliki koefisien positif. Hal tersebut berarti bahwa terdapat peningkatan profitabilitas, ukuran perusahaan dan ukuran KAP meningkatkan pengungkapan tanggung jawab social perusahaan. Sementara untuk variabel gender diversity koefisien yang ditunjukan adalah negative. Hal ini berarti bahwa keberadaan anggota direksi perempuan tidak meningkatkan pengungkapan tanggung jawab social perusahaan.

\section{Pengujian Hipotesis} a. Uji t

Tabel 1.9

Uji t

$\begin{array}{llll}\text { Variabel } & \text { t } & \text { Sig. } & \text { Keterang }\end{array}$

\begin{tabular}{llll}
\hline & hitun & & an \\
& g & & \\
\hline Gender & - & 0,39 & Berpengar \\
Diversity & 0,898 & 9 & uh negatif \\
Profitabilit & 1,194 & 0,27 & $\begin{array}{l}\text { Berpengar } \\
\text { as }\end{array}$ \\
$\begin{array}{l}\text { Ukuran } \\
\text { Perusahaa }\end{array}$ & 5,253 & 0,00 & $\begin{array}{l}\text { Berpengar } \\
\text { uh positif }\end{array}$ \\
n & & 1 & \\
Ukuran & 0,334 & 0,74 & Berpengar \\
KAP & & 8 & uh negatif
\end{tabular}

Sumber : Data sekunder diolah

Berdasarkan tabel di atas, dapat dijelaskan sebagai berikut :

Gender Diversity berpengaruh positif terhadap pengungkapan tanggung jawab social perusahaan

Pengujian hipotesis pertama untuk menguji apakah terdapat pengaruh positif terhadap pengungkapan tanggung jawab social perusahaan. Hasil pengolahan data diperoleh bahwa nilai $\mathrm{t}$ sebesar $-0,898$ dengan tingkat signifikansi sebesar 0,399 lebih tinggi dari $\alpha=0,05(0,399>0,05)$. Hal ini berarti dalam pengujian hipotesis pertama $\mathrm{H}_{0}$ diterima dengan tingkat signifikansi 5\%. Sehingga dapat disimpulkan bahwa gender diversity berpengaruh negative terhadap pengungkapan tanggung jawab social perusahaan.

Profitabilitas berpengaruh positif terhadap pengungkapan tanggung jawab social perusahaan

Pengujian hipotesis kedua untuk menguji apakah profitabilitas berpengaruh positif terhadap pengungkapan tanggung jawab social perusahaan. Hasil pengolahan data diperoleh bahwa nilai t sebesar 1,194 dengan tingkat signifikansi sebesar 0,271 lebih tinggi dari $\alpha=0,05(0,271>0,05)$. Hal ini berarti dalam pengujian hipotesis kedua $\mathrm{H}_{0}$ diterima dengan tingkat signifikansi $5 \%$. Sehingga dapat disimpulkan bahwa profitabilitas 
berpengaruh negatif terhadap pengungkapan tanggung jawab social perusahaan.

$\mathrm{H}_{3}$ : Ukuran perusahaan berpengaruh positif terhadap pengungkapan tanggung jawab social perusahaan

Pengujian hipotesis ketiga untuk menguji apakah ukuran perusahaan berpengaruh positif terhadap pengungkapan tanggung jawab social perusahaan. Hasil pengolahan data diperoleh bahwa nilai $\mathrm{t}$ sebesar 5,253 dengan tingkat signifikansi sebesar 0,001 lebih rendah dari $\alpha=0,05(0,001<0,05)$. Hal ini berarti dalam pengujian hipotesis ketiga $\mathrm{H}_{0}$ ditolak dengan tingkat signifikansi $5 \%$. Sehingga dapat disimpulkan bahwa ukuran perusahaan berpengaruh positif terhadap pengungkapan tanggung jawab social perusahaan.

\section{Ukuran KAP berpengaruh positif terhadap pengungkapan tanggung jawab social perusahaan}

Pengujian hipotesis keempat untuk menguji apakah terdapat pengaruh positif terhadap pengungkapan tanggung jawab social perusahaan. Hasil pengolahan data diperoleh bahwa nilai $\mathrm{t}$ sebesar 0,334 dengan tingkat signifikansi sebesar 0,748 lebih tinggi dari $\alpha=0,05(0,748>0,05)$. Hal ini berarti dalam pengujian hipotesis keempat $\mathrm{H}_{0}$ diterima dengan tingkat signifikansi $5 \%$. Sehingga dapat disimpulkan bahwa ukuran KAP berpengaruh negative terhadap pengungkapan tanggung jawab social perusahaan.

Dari kelima variabel independen yang telah diuji, yaitu gender diversity, profitabilitas, ukuran perusahaan dan ukuran KAP, dapat disimpulkan bahwa hanya variabel ukuran perusahaan yang memiliki pengaruh signifikan terhadap pengungkapan tanggung jawab social perusahaan. Tiga variabel lainnya, gender diversity, profitabilitas dan ukuran KAP tidak berpengaruh signifikan terhadap pengungkapan tanggung jawab sosial perusahaan.

b. Uji F (Simultan)

Tabel 5.9

Uji F

\begin{tabular}{llll}
\multicolumn{4}{c}{ Uji F } \\
Model & $\begin{array}{c}\text { F } \\
\text { hitun }\end{array}$ & Sig. & Keterangan \\
& \multicolumn{1}{c}{ g } & & \\
\hline Regres & 59,49 & 0,00 & Berpengaru \\
i & 5 & 0 & h negatif
\end{tabular}

Sumber : Data sekunder diolah

Data yang tersaji pada tabel 5.9 nilai $\mathrm{F}$ hitung $=59,495$ memiliki probabilitas sebesar 0,000. Dengan hasil nilai probabilitas lebih rendah dari $\alpha=$ $0,05 \quad(0,000<0,05)$ berarti bahwa secara bersama-sama pengungkapan tanggung jawab social perusahaan dapat dijelaskan oleh variabel gender diversity, profitabilitas, ukuran perusahaan dan ukuran KAP.

\section{Pembahasan}

Berdasarkan hasil pengolahan data yang dilakukan terhadap annual report perusahaan sampel, pengungkapan tanggung jawab social perusahaan tertinggi yaitu oleh PT. Indofood Sukses Makmur, Tbk dengan pengungkapan masing-masing pada tahun 2015, 2016 dan 2017 sebanyak 86 poin. Sedangkan pengungkapan terendah oleh PT. Sekar Bumi, Tbk dengan pengungkapan masing-masing pada tahun 2015, 2016 dan 2017 sebanyak 24 poin. Hasil yang diperoleh menggambarkan tingkat pengungkapan tanggung jawab social perusahaan pada perusahaan sector makanan dan minuman yang terdaftar di Bursa Efek Indonesia masih rendah. Hal ini berarti peraturan yang dibuat terkait pengungkapan tanggung jawab social belum efektif dilaksanakan oleh perusahaan sector makanan dan minuman. Perusahaan mengungkapkan komponen tanggung jawab social perusahaan hanya sebagai bentuk ketatan terhadap peraturan 
yang telah ditetapkan oleh badan regulasi, seperti Bapepam dan BEI.

Berdasarkan hasil pengujian yang telah dilakukan, pengaruh gender diversity terhadap pengungkapan tanggung jawab social perusahaan diketahui tidak berpengaruh signifikan terhadap pengungkapan tanggung jawab social perusahaan. Hal tersebut dapat diartikan keberadaan anggota direksi wanita dalam persentase tertentu belum mampu mempengaruhi pengungkapan tanggung jawab perusahaan. sementara wanita pada umumnya memiliki pemikiran yang lebih mendetail terkait pengambilan analisis keputusan (Hadya dan Romi, 2018). Hasil penelitian ini didukung penelitian yang dilakukan oleh Dima (2016).

Berdasarkan hasil pengujian yang telah dilakukan, pengaruh profitabilitas terhadap pengungkapan tanggung jawab social perusahaan diketahui tidak berpengaruh signifikan terhadap pengungkapan tanggung jawab social perusahaan. Bentuk alasan yang melandasi hal tersebut yaitu perusahaan menganggap tidak perlu melaporkan hal-hal yang dapat mengganggu informasi kesuksesan perusahaan, saat laba tinggi (Nanda, 2016). Kerugian kompetitif akan ditimbulkan karena perusahaan harus mengeluarkan biaya tambahan untuk mengungkapkan informasi CSR (Anggraini, 2006). Hasil penelitian ini didukung penelitian yang dilakukan oleh Nanda, (2016) dan Siregar dan Bachtiar (2010).

Berdasarkan hasil pengujian yang telah dilakukan, pengaruh ukuran perusahaan terhadap pengungkapan tanggung jawab social perusahaan diketahui berpengaruh signifikan terhadap pengungkapan tanggung jawab social perusahaan. Hal ini berarti besar maupun kecil ukuran sebuah perusahaan akan berpengaruh terhadap keluasan pengungkapan tanggung jawab social perusahaan. Pada umumnya perusahaan besar mampu memperlihatkan kinerja yang lebih tinggi, salah satunya dengan cara mengungkapkan tanggung jawab social lebih rinci. Selain itu makin besar suatu perusahaan biasanya tuntutan performa dalam melakukan kegiatan social juga lebih tinggi. Hasil penelitian ini didukung penelitian yang dilakukan oleh Kurniawati (2013) dan Singgih (2017).

Berdasarkan hasil pengujian yang telah dilakukan, pengaruh ukuran KAP terhadap pengungkapan tanggung jawab social perusahaan diketahui tidak berpengaruh signifikan terhadap pengungkapan tanggung jawab social perusahaan. Hal ini terjadi bisa dikarenakan KAP menganggap bahwa pengungkapan tanggung jawab perusahaan bukanlah hal yang krusial dalam annual report sehingga dianggap tidak perlu memberikan rekomendasi kepada perusahaan untuk mengungkapkan tanggung jawab social lebih luas lagi, sesuai dengan Indeks GRI. Hasil penelitian ini didukung penelitian yang dilakukan oleh Naser dan Yousef (2013) dan Khasharmeh dan Desoky (2013).

\section{SIMPULAN}

Berdasarkan proses pengujian yang telah dilakukan, maka dapat ditarik kesimpulan sebagai berikut :

1. Gender diversity, profitabilitas dan ukuran KAP tidak berpengaruh signifikan terhadap pengungkapan tanggung jawab social perusahaan pada perusahaan sector makanan dan minuman yang terdaftar di Bursa Efek Indonesia.

2. Ukuran perusahaan berpengaruh signifikan terhadap pengungkapan tanggung jawab social perusahaan pada perusahaan sector makanan dan minuman yang terdaftar di Bursa Efek Indonesia..

3. Gender diversity, profitabilitas, ukuran perusahaan dan ukuran KAP secara bersama-sama berpengaruh signifikan terhadap pengungkapan tanggung jawab social perusahaan pada perusahaan sector makanan dan 
minuman yang terdaftar di Bursa Efek Indonesia..

\section{DAFTAR PUSTAKA}

Anggraini, Fr. Reni Retno. 2006. Pengungkapan Informasi Sosial dan Faktor faktor yang Mempengaruhi Pengungkapan Informasi Sosial dalam Laporan Keuangan Tahunan (Studi Empiris pada Perusahaan-perusahaan yang Terdaftar di Bursa Efek Jakarta). Simposium Nasional Akuntansi IX, Padang, 23-26 Agustus 2006.

Anggraini, Fr. Reni Retno. 2006. Pengungkapan Informasi Sosial dan Faktor faktor yang Mempengaruhi Pengungkapan Informasi Sosial dalam Laporan Keuangan Tahunan (Studi Empiris pada Perusahaan-perusahaan yang Terdaftar di Bursa Efek Jakarta). Simposium Nasional Akuntansi IX, Padang, 23-26 Agustus 2006.

Anggraini, Fr. Reni Retno. 2006. Pengungkapan Informasi Sosial dan Faktor faktor yang Mempengaruhi Pengungkapan Informasi Sosial dalam Laporan Keuangan Tahunan (Studi Empiris pada Perusahaanperusahaan yang Terdaftar di Bursa Efek Jakarta). Simposium Nasional Akuntansi IX, Padang, 23-26 Agustus 2006.

Dima, Utama A. 2016. Pengaruh Dewan Direksi Wanita dan Struktur Kepemilikan Terhadap Pengungkapan CSR Pada Perusahaan Pertambangan yang Terdaftar Di Bursa Efek Indonesia. Universitas Airlangga.

Elder Healy, Paul M., dan Krishna G. Palepu. 2001. "Information Asymmetry, Corporate Disclosure, and the Capital Markets: A Review of the Empirical Disclosure
Literature". Journal of Accounting and Economics, 31 (1-3), 405-440

Hadya, Riska dan Romi Susanto. 2018. Model Hubungan Antara Keberagaman Gender, Pendidikan dan Nationality Dewan Komisaris Terhadap Pengungkapan Corporate Social Responsibility. Jurnal Benefita 3 (2), Juli 2018.

Jensen, M., dan Meckling, W. 1976. Theory of the firm: Managerial behaviour, agency costs and ownership structure. Journal of Financial Economics. 3(4), 305-360

Khasharmeh, Husein A and A.M Desoky. 2013. On-line Corporate Social Responsibility Disclosure; The Case of The Gulf Cooperation Council (GCC) Countries. Global Review of Accounting and Finance, Vol.4 No.2 September 2013. Pp.39-64.

Kurniawati, F. A. 2013. Pengaruh Profitabilitas, Leverage dan Ukuran Perusahaan terhadap Luas Pengungkapan Tanggung Jawab Sosial Perusahaan pada Perusahaan Pertambangan Di Bursa Efek Indonesia Periode 2009-2012. Universitas Negeri Yogyakarta.

Machfoedz, Mas'ud. 1994. Financial Ratio Characteristic Analysis And The Prediction Of Earning Change In Indonesia. Kelola No.7 pp: 114133

Nanda, Ulfa L. 2016. Pengaruh Corporate Governance dan Karakteristik Perusahaan Terhadap Pengungkapan Tanggung Jawab Sosial Perusahaan Dengan Ukuran Perusahaan Sebagai Variabel Moderasi (Studi Empiris Pada Perusahaan Yang Terdaftar Di Bursa Efek Indonesia). Tesis. Magister Ilmu Akuntansi,Universitas Jambi.

Nasser, Kamal dan Yousef Hasan. 2013. Determinants of Corporate Social Responsibility Reporting: Evidence from an Emerging Economy. Journal of Contemporary Issues in Business Research, Vol.2 Issue No.3 2013. 
Nugroho, M. N., \& Yulianto, A. 2015. Pengaruh Profitabilitas Dan Mekanisme Corporate Governance Terhadap Pengungkapan CSR Perusahaan Terdaftar Jii 2011-2013. Accounting Analysis Journal, 4(1), $1-12$.

Nurkhin, A. 2009. Corporate Governance dan Profitabilitas; Pengaruhnya terhadap Pengungkapan Tanggung Jawab Sosial Perusahaan (Studi Empiris pada Perusahaan yang Terdaftar di Bursa Efek Indonesia).

Peraturan Pemerintah Republik Indonesia No. 47 Tahun 2012 tentang Tanggung Jawab Sosial dan Lingkungan Perseroan Terbatas.

Purnasiwi, Jayanti dan Sudarno.2011. Analisis Pengaruh Size, Profitabilitas dan Leverage Terhadap Pengungkapan CSR Perusahaan yang Terdaftar Di Bursa Efek Indonesia. Skripsi. Universitas Diponegoro; Semarang.

Rakhiemah, A. N., \& Agustia, D. 2012. Pengaruh Kinerja Lingkungan Terhadap Corporate Social Responsibility (CSR) Disclosure Dan Kinerja Finansial Perusahaan Manufaktur Yang Terdaftar Di Bursa Efek Indonesia, 1-31.

Rovers, Mijntje L. 2010. Female Directors on Corporate Boards Provide Legitimacy to A Company. Available http://ssrn.com/abstract=1411693.

Sanjaya, O., Taufik, T., \& L, A. A. 2014. Pengaruh Good Corporate
Governance, Profitabilitas, Dan Ukuran Perusahaan Terhadap Pengungkapan Tanggung Jawab Sosial Perushaan Pada Perusahaan Real Estate Dan Property Yang Terdaftar Di Bursa Efek Indonesia (2010-2011), 1(1), 1-15.

Sembiring, Eddy Rismanda. 2005. Perkembangan Corporate Social Responsibility di Indonesia. Simposium Nasional Akuntansi VIII; Solo.

Singgih, M. Lilik, F dan Rizqi, A. 2017. Determinan Tingkat Pengungkapan Tanggung Jawab Sosial Perusahaan Manufaktur Subsektor Makanan dan Minuman Di BEI. Bisma, Jurnal Bisnis dan Manajemen, Vol.11 No.3 September 2017, Hal.259-270.

Siregar, S Veronica and Yanivi Bachtiar. 2010. Corporate Social Reporting; Empirical Evidence from Indonesian Stock Exchange. International Journal of Islamic and Middle Eastern Finance and Management, Vol.3, No.3,2010, pp.241-252.

Z, S. F., Makhdalena, \& Trisnawati, F. 2016. Pengaruh Komisaris Independen Dan Komite Audit Terhadap Pengungkapan Corporate Social Responsibility Perusahaan Pertambangan Di Bursa Efek Indonesia Periode 2012 s.d 2014, $3(2), 1-11$.

UU No.40 Tahun 2007 Tentang Perseroan Terbatas. 